\title{
大阪府を中心とする四間取り民家の変遷と特質
}

\author{
正会員林野 全 孝*
}

本稿は昭和 32 年度以降大阪府教委の依託により 10 ケ 年にわたり府下全域の民家調查を行なった結果に基ずく 研究概要であって, 関連性の濃い大阪府周辺の民家の資 料も含め, これらを復原考察の結果, 史的考察を行な い，かつ全国的視野から大阪府の民家の位置ゔけを行な う中で，その特色を明らかにするものである。

なお本稿を草するに当り，終始御指導をいただいた大 阪南大浅野清教授，同白木小三郎教授，同鈴木充講師， 共に調查に協力下さった大阪工大青山賢信助教授, 奈良 国立文化財研究所宮沢智士技官，および調查に助力いた だいた大阪市大, 近畿大学の関係各卆業生の方々, 関係 諸舁庁の方々，並びに快よく調査させて下さった各住宅 所有者の方々に対して厭く感謝の意を表したい。

序 説

戦前から昭和 30 年頃までの民家研究の赹勢では, 田 の字形（四間取り）民家が全国の主流をなして分布して いると考えられていたのであるが，戦後の急激に進んだ 民家研究の段階では，四間取り民家の原形は広間をむつ 三間取りであって，それが近世後半以後において広閒を 二分することによって四間取りを生じたことが各地の実 例について明らかにされ，さらに妻入縦割型やその他の 系統を異にする型の存在と分布も次第に明らかにされて きたのであるが，特に広間型の分布は圧倒的に広く，北 は東北から南は九州に亘って一大勢力をもつことが判明 してきた。その段階で近畿の四間取りも, その祖形は広 間型に帰するのではないかと考える向きすら生じだ。

大阪市大建築史研究室では, 大阪府教委の依託を受け て，昭和 32 年度以来府下の民家を調査してきたが，最 初の段階ではできるだけ古い民家を調査し，これを復原 し，当地方民家の祖形を明らかにすることに力をそそい だが，すでにこの段階でも北部の地方に妻入縦割型民家 の先行する他は府下には四閒取りの平面をもつものしか ないことを知った。これらはいずれも，閒取りは主屋の 土間妻側にマヤとカマヤを配し, 居室は基本的に表にク チノマとザシキ，裏にダイドコとナンドを田の字に配す る。また梁は水平に表の桁から裹の入側通りまで通る が, 前後の室境上の桁や梁上にも支点があって, 連続梁 となる。従って梁間は一般に広く 3.5 間程度におよぶ。 また水平梁を利用してその上には直ちに䍃子天并を張

* 近畿大学助教授. 工博

（昭和 44 年 2 月 3 日本楟受理 ・討論期限昭和 44 年 12 月末日)
り，その上をツシとする。小屋組には又首組または束立 の二種の方法がみられる。以上のように共通して四間取 りであって，はなはだ簡明な構造をとっているのであ る。しかしさらに調查を徽底し，正確な結論を得るた め, 組織的な密度高い捜查に基づてて，その発展段階を も明らかにしたうえ，各遺構の位置ゔけをするととも に，建築年代の明らかな資料を見出すことにより，各建 物の奏年代を推定して行く方法をとることとした。そこ で 35 年以降大阪府全域に亘り，農家とそれに密接な関 係をもって発生したと考えられる町家をも含めて再調查 を行ない，41 年度まで 7 年間を費して府下一川の調查 を一応終ったのである。なお近隣の奈良盆地については 関連調查の必要を感じたのであるが，全県下に旦る高密 度調查は不可能であったので，関係のついた地域につい て調查し，全体の傾向をとらえることにつとめた。以上 の結果建築年代の明らかなものもかなり発見され，全体 として系統立った把握が可能となり, その変遷の動问も 明らかになってきた。しかし特に泉南地方では，喰い違 い三間取り型ともいうべき古い型の平面をもつ民家が先 行していることが判明した。この型の古形式は四閒取り のうちクチノマがなく，従ってダイドコが土閒方へ突出 するが，ザシキが広いために室が互に喰い違う間取りと なる(第 16 図-C参照)。この種のものにはカマヤを独 立して土間に設けるものはほとんどない。しかし，以上 の点を除けば，構造的にも四間取りの場合と全く同様の 手法を示しているのは注目しなければならない。そこで その分布を追って紀ノ川，吉野川沿いに西吉野まで進 み, 同型の特に古いものまで発見できたのは大きい収獲 であった。この喰い違い三間取り型は，四間取り型と構 造においても機能においても極めて近親性をもち，四間 取り型の祖形である公算が強いと考えられ，四間取り型 の本質を考察する上で有力な資料となったのである。

\section{1. 四間取り民家の調查と史的考察}

調查結果を総合すると，棟札または記録で年代の明確 な遺構は, 奈良県の農家および町家を含めて 29 棟の多 きに達し, 祈裙札や過去帳などから年代をほぼ推定でき るものはさらに多く, 約 50 棟にも達した。しかし，そ れら年代の判明し，かつ保存状態のかなりよいものは， 実は元禄 (18 世紀初頭) 以降に多く，17 世紀のものは 極めて少なかった。

以上収集した畿内の膨大な凟料（予備調查で約 2,000 
棟，記録に止めたものはその約半数）を整理することに よって, 当地方の民家の 3 世紀に亘る変遷過程を明らか にすることができたのであるが，それらの発展傾向は， 特に高密度に調查した大阪府の民家と平行していること がわかった。しかしこれらの資料を網羅して叙述するこ とははなはだ繁雑で，反って理解を困難にするので，大 阪府のうち 17 世紀の建築と推定される遣構, 年代の確 実な遺構に限って網羅し，その他の類品の多いものにつ いては変遷を知る上で基準となる重要かつ保存状態のよ い遺構に限ることとし，それらのうち 51 棟を蕨選して 年代順に配列した ${ }^{2)}$ 。その結果を見ると，発展の順序は 必ずしも実年代とは轡密に一致しないので，奈良県側の 年代の確実な農家遗構をも配列の基準として用い，かつ 年代の確実な町家遺構もその配列の参考としてこれを利 用し，四間取り農家の全体の流れを察知するょうにつと めてみた。

ところで，これらの変遷を示す個々の部分については あるものは進歩性を示し，あるものは古い手法を残して 保守性を示す（特に 18 世紀前半に著しい）傾向がみら れ，必ずしも合理的に並ばないことが分ったのである が，大局的にみると発展の方向は明確に㨄みとれたので ある。しかし，これらの遺構をここにすべて解説するこ とは不可能であるので，主要なる発展の方向を要約でき る遺構 8 棟を択んでその要点のみ概説したい。

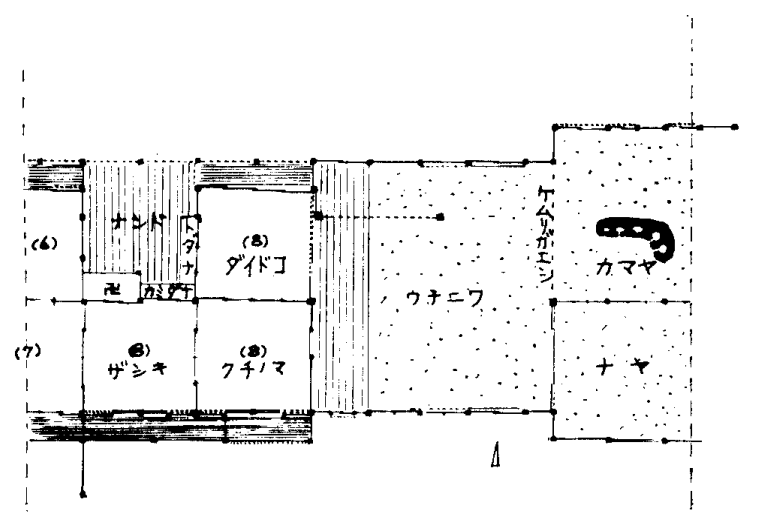

第 1 図 吉村姴治野家住宅復原平面図

吉村要次郎家住宅 (重文) 羽曳野市島泉 (第 1 図参照) この家は元和 2 年 (1616) に建築されたと考えられて おり，先年の修理で浅野清博士により復原されたもので ある3”。主屋のうち，ウチニワと，それに接する居室の 四室は当初の状態をよく残している。ここで特に注意を 要するのはナンド迴りと外迴りの手法である。ナンドと ザシキ間には仏壇と神棚（?）がナンド内に入り込んで 設けられて，この間は閉される。またナンドとダイドコ 間に棚があって，ナンド内は凹凸のある室となる。また この間の開口（入口）は半間のみで，板戸を片引にして 入る。ナンドの他の側は壁で閉されていたらしく，極め て関鎖性の強い室となる。外廻りの柱䦥開口方式は，柱 を一間ごとにたてて，そのうち半間に壁を設け板戸と障

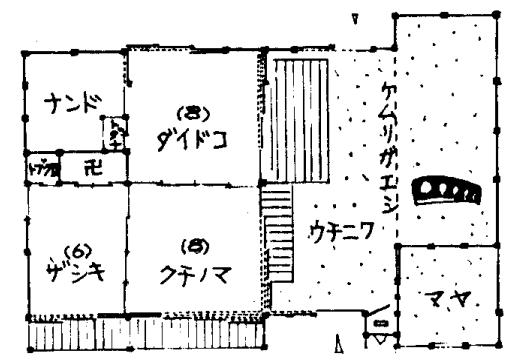

第 2 图山本傐一家住宅復原平面図

子を片引にして閉じる。従って雨戸は用いない。その他 の室境では，原則としては中間に柱をたてず，室幅一ぱ いに差鴨居を用いて開閉する。

山本信一家住宅 河内長野市小深 (第 2 図参照)

当住宅は吉村家住宅よりも若干年代が降ると考えられ る。ナンド迴りの方式は入口の敷居が高められているこ と，仏壇と並んで戸棚があることを除いて，吉村家住宅 の場合と変らないが，外迴りの開口では，すでに柱を一 間ごとにたてないで, 室幅一ぱいに差鴨居（つき止め 溝）を用いて開放する。このような方法が 17 世紀の前 半ですでに使用されていることは注意す心゙きであろう。

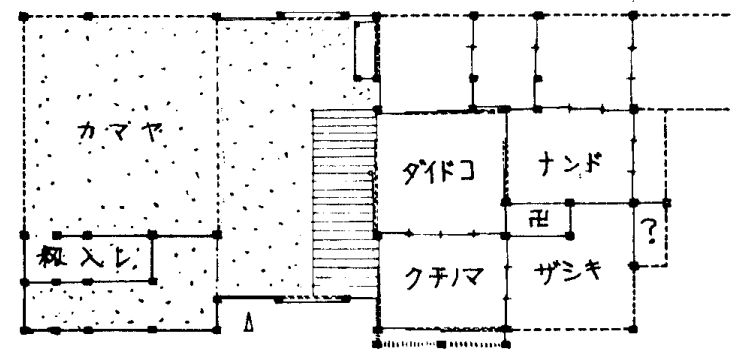

第 3 図村井好之助家住宅復原平泊図

村井好之助家住宅（重文）奈良県北暮城郡新庄（第 3 図参照)

この家には元禄 13 年 (1700) に竝工したことが普請 帳によって明らかである゙”。主屋は四間取りの裹にも室 をもつ梁行に大きい家である。ナンドとザシキ間は仏壇 のみとなって，棚の位置は壁となる。またダイドコとの 境も 1.5 間の差鴨居（つき止め）を通し，開放される。 また妻側も開放されていたと考えられる。外迴りは改造 がはなはだしいが，クチノマ謷は，山本家住宅と同様で あり，他の個所では雨戸を用いていたことが普請帳によ って知られる。このように 18 世紀に入ると一挙に開放 化が進み進歩性が強く認められる。

山添文造家住宅 北河内郡交野町寺（第 4 図参照）

この家には宝永 2 年 (1705) の棟札があって建築年代 が確実である。ナンドとダイドコ境は 1.5 間の差鴨局で 開かれている点は類似するが，ナンドとザシキ境が仏壇 と床で閉鎖されているのは村井家住宅より反って古めか しい。また外迴りに 1 間ごとに柱を配し，雨户を用いず 開閉する方式は前記声村家住宅の埸合と全く同様で，こ 


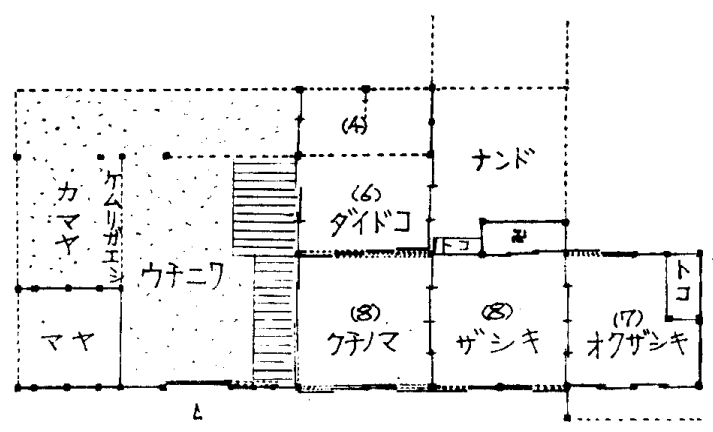

第 4 図山添文造家住宅復原平面図

れも古式である。このようにほとんど同年代に建てられ た村井，山添雨家住宅の場合，進歩性を示寸例と保守性 を示す例が例存していることは注目されよう。

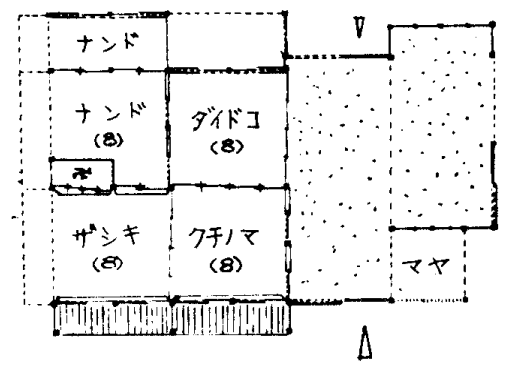

第 5 図中前秀逸家住宅復原平缅図

中前秀冕家任: 宅 奈良県吉野郡下市町阿知賀（第 5 図 参照)

この家は系図の書込みから享保 18 年 (1733) に建て られたことが確実である。ナンドとザシキ間 2 間のうち 1 間に仏壇を配するのは村井家住宅も同様であるが，残 る 1 間を開放して雨室の通行を可能にしているのは進歩 している。またナンドとダイドコ境 2 閒幅の中央に柱を たて，各々板戸 2 枚と障子を入れるのは，当住宅の外迴 りの柱閒装置と同じであり，この個所にそのような方式 を用いるのは翼例であるが，村井，山添両家住宅の手法 よりむしろ古風と思われる。

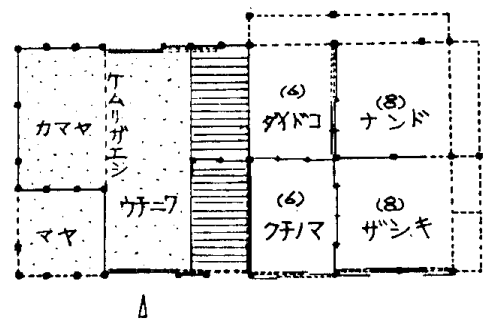

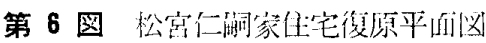

松宮仁嗣家 住宅枚方市杉（第 6 図参照）

この家は筧保 4 年 (1741) の棟札があって建築年代は 明らかである。ナンドとザシキ境は中央に柱をたて，そ の大半を壁とするが，妻奇り半閒に開口のあったことが 認为られた。この閣の仏壇はザシキの妻側に移され，棚 （？）と並ぶこととなる。な打当住宅よりやや湖ると推 定している田中宇之松家住宅（枚方枋枚方）など若干の
遺構に，この間が壁のみで閉されているものもみられ た。外迴りの柱間装置の一部には， 3 本溝の差鴨居を用 いて，外の一本を雨戸用とし，戸袋に入れる方式をとる ようになる。これは今までに見られなかった新しい方法 であるが，その最も早く用いられる例に当家住宅より約 20 年ほど溯ると考えられる堺市大森の河片忠兵衛家住 宅がある。

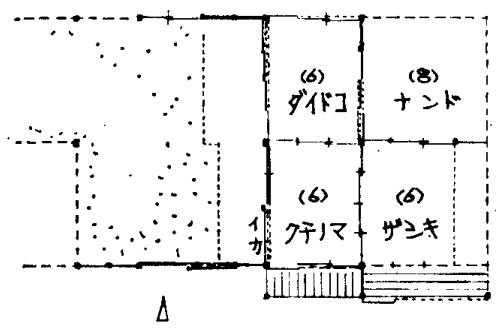

第 7 図土武治正家住宅復原平面図

上武治正家住宅 枚方市穂谷 (第 7 図参照)

寛政 2 年 (1740) の建設記録によって建築年代注明確 である。ナンドとザシキ境は, 最早や 1.5 閒の差鴨居を 用いて開放されてしまう。しかしナンドとダイドコ境 は，なお村井家住宅で用いていたように間のつき止めの ある差鴨居を用いる。しかし，かっての閉鎖的なナンド の面影は完全になくなる。外廻りの柱間装置も，前䓵松 宮家住宅の一部に用いていた手法と，縁侧に雨戸を用い る方法を併用する。この方法は 19 世紀に入ると，ほと んどの家にみられるようになる。また一般に平面は，こ の頃に定形化してしまい。以後，目新しい変化は見せな くなる。

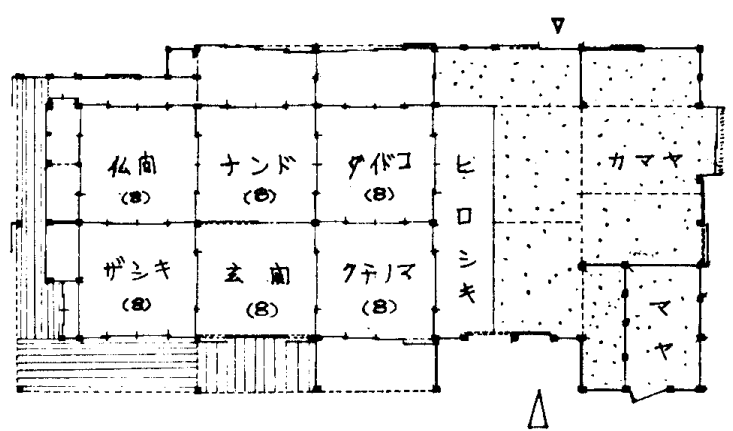

第 8 图杉本方太䬦家住宅復原平面図

杉本市太郎家住宅 奈良県生駒町上（第 8 図参照）

安政 2 年 (1855) の棟札と普請帳 ${ }^{5}$ があって建築年代 は明らかである。別座敷が居室の妻侧に取り付いていて 桁行に長く六間取りとなり，元来のザシキが玄関とな る。従って玄関の裏がナンドであるわけであるが，各室 境はすべて開放されてしまって，ナンド自体もその性格 を失ってしまう。

以上のように，当地方の民家は，一貫して四間取りを 基準とし，かつ構造上ほとんど変化を認めないのである がわずかにナンド迴りにおいて，次室境に配していた 装置が他の場所に移されて，次第に開放されてゆく傾向 
があることと，外迴りの柱間装置が閉鎖的なものから開 放的に進んで行く他は，きわだった変化を見なかったの である。

なお付言すると，現状で土間を表裏に仕切る結界のあ る農家ははなはだ多いのであるが，これはすべて幕末近 くに附加されたもので（町家にはミセと居室部分を分け るために, 結果はもら少し早くから用いられていた)， 結界を設けると同時に土間裹方のヒロシキが浜床となっ てカマヤ方に突出し，ここがダイドコの機能をもってき て, 元来のダイドコは居室の一つに使用目的を変化させ るようである。

\section{2. 喰い違い三間取り民家の発見}

以上のように大阪平野や奈良盆地における民家はすべ て古くから四間取りであることがわかってきたが，高密 度な復原調查を進める中で, 大阪府の南端, 泉南郡一帯 において，喰い違い三間取り型と称すべき型が四間取り 型に先行して分布していることを発見した。この型は前 述のように，居室は三室を基本としてダイドコが土間に 突出するため, 棟下の列では大黑, 中大黑, 内大黒の各 柱と，さらに奥妻入側と柱が一間ごとにたち，表向きの ザシキと裹向きの二室間が表裏に二分されるため，構造 上この上にも支点をおき連続梁となり，かつ宝が一閒お きに桁行を分割するために，構造上はなはだ有効な間取 りとなっている。これはこの型の基本であって，熊取の 中家住宅のような豪壮な家では同じ型でも室を增して複 雑之なる。な㧍この型の梁架構の方法は，四間取り型の 場合と全く同じであることは重要である。

ところで，この型の分布を求めて，さらに南下して調 查を行なったところ, 紀ノ川流域から吉野川を溯り西吉 野地方に古い遺構が多数分布していることがわかったの で，それらの主要なものを含め 21 棟について，この型 の変遷過程を追究し，史的考察を行なっだ)。しかし本 稿ではその全部を解説することは繁雑であるので, 理解 しやすいようにそのうち变遷つ過程を要約できる重要な 遺構を㛜選して以下概観したい。

西田敏一家住宅 (重文) 奈良眎吉野郡西吉野村鹿場(第 9 図参照)

この家は，表のザシキが 12 壘という広いもので（現 在この室は差鴨居で二分されているが，この虔鴨居は当 初からあったかどらかは明らかにできない。あるいは当

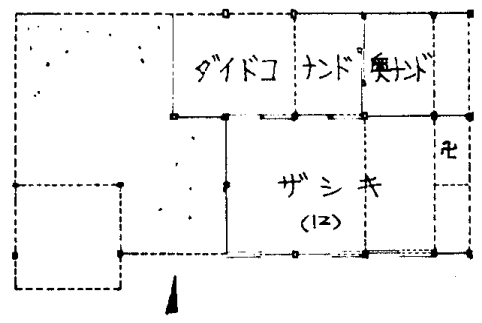

第 9 图西团敏一家住宅復原平面図
初 8 畳と 4 畳に分割されていた可能性も㐫る)，さらに はナンドを二室もって，ダイドコを土間に突出させてい たと考えられる。柱は一間ごとにたち，土閒とザシキお よびダイドコの突出部分の表法壁で閉じる。表裏室境の らち，奥ナンドとの境は板壁であるが，その一間土間方 のナンド境には敷居を高くに入れた踏み込みを持ち，半 間を壁として片引で開閉する。この方法は畿内全城を通 ビて当家住宅のみにしか見られず（改造ははなはだしい 室町時代の建設と推定されている西吉野堀家住宅にも西 田家住宅と 同様の痕跡を見る)，その建築時期は はなは だ古いと考えられる。

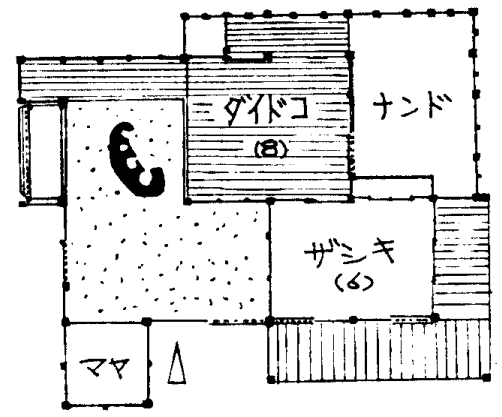

第 10 図 束田中利一家住宅愎原平面图

東田中利一家住宅 奈良県西吉野村湯川（第 10 図参 照)

この家は居室が三室（ナンドが一室）で仏壇がナンド とザシキ間に設けられる。ザシキの妻側に縁を設けるの はやや開放的になるが，ダイドコとナンド間の入口は半 間で，踏み込みをもつ。その他は上記西田家住宅と類似 して，建筑年次の古さが察知される。なお西田家住宅と も，この段階では差鴨居は使用していないのである。

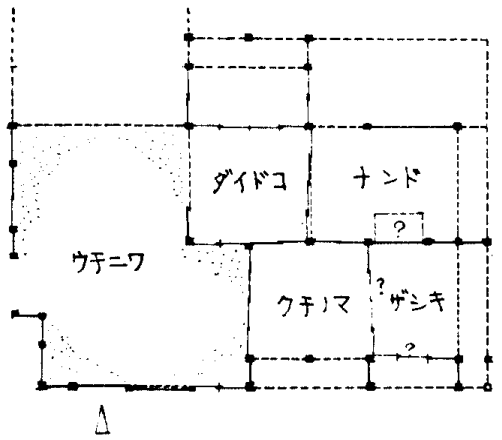

第 11 図 奥ノブ子家住宅復原平耑四

奥ノブ子家住宅 泉传野扵樫讲 第 11 図参照

当家は文書から推察して，慶長〜元和の間に建てられ たと考えられる。主屋の䁁にも化を延して室を設け，木 割も太く，はなはだ豪壮な構えを見せる。主屋の表には 二室を配し(この室境の差鴨居は他と比べて調子が新し く，あるいは後補の可能性もある)，裹二室と 互に喰い 違い，ダイドコはやはり一間土間方へ突出する。ナンド ははなはだ閉鎖的であるが，ダイドコとナンドの境は障 子と板戸を併用し，板戸は雨戸のように戸袋に納めると 


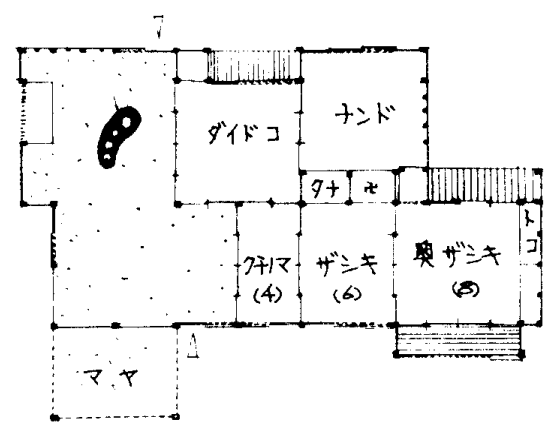

第 12 図 小川孫四郎家住宅得原平酒図

いら特殊な装置をとっている。

小川孫四郎家住宅 和歌小県橋本市市脇（第 12 図参 照)

この家には元禄 14 年の棟札があって，この種の民家 で年代の明確な唯一の遺構であるのは貴重である。この 頃になると，四間取りの村井家住宅などと同様ナンドと ダイドコ境は開放されるが, 表のザシキは内大黒柱より 表方一差鴨居を入れて二分され，土間側の部分は 4 畳の クチノマとなる。ところで，橋本沛の西北に扔けるかつ らぎ山頂近くで発見した守安義雄，中谷伊太郎雨家住宅 も, この家に極めて類似していて，作代的にもあまり差 がみられないものである。

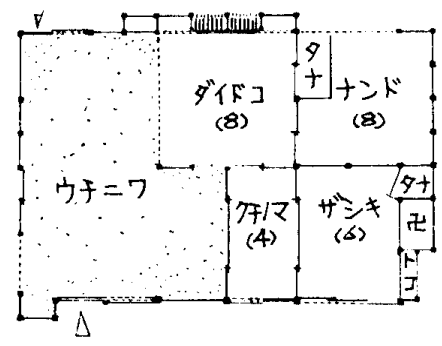

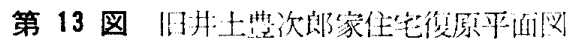

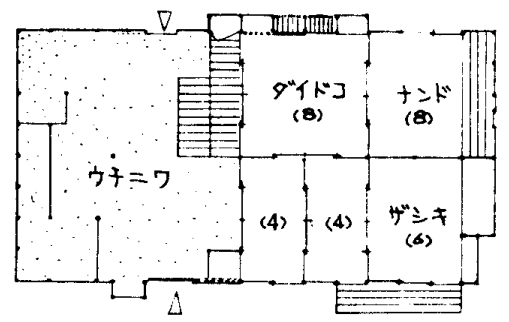

第 14 图旧半上党次蚛家住宅现状平面图

旧井上豊次郎家住宅 泉南町信達六尾（第 13 図, 第 14 図参照)

この家は 18 世紀前半頃と推定できるるので当初は小 川家住宅と同様主屋の表に 4 畳のクチノマとザシキがあ った。しかし現状では大黒柱から表侧一差鴨居を入れ て，さらに長い 4 置を加え，ダイドコの突出をなくして いる。そうすると，ここに 4 眰が二室竨ぶこととなる が，実際に法雨室境の建具をとって，8思のクチノマと して使っていたらしい。そうすると整型四間取りとな る。浆南地方には現在四間取りのものでもこの種の改造
を経た例は多い。なおこの家のナンド入口は狭く，ダイ ドコに面して戸棚があり，かつナンド，ザシキ間は壁で 䦥されるなど古い方式がみられる。

以上のようにこの型には，少なくとも 16 世紀まで溯 り得ると考えられる遺構をも含めて, 17 世紀以前の古 いものがかなり存在し，その発展過程も明らかにするこ とができたのである。つまりこの型は, 17 非紀末近く になると, 内大黑柱から㪇側柱に差鴨居を入れて, ザシ キを二分し，4罡のクチノマを作り，さらに 18 此紀後 半に入ると, 大黒柱から表側柱に差鴨居を入れてダイド コの突出を修正し，クチノマを広くとって整形四間取り 型に発展して行くことがわかった（この閖取りが長く三 間取りにとどまったのは表側に広い作業空間をとったか らであって，そらする方が構造的に有利であったことは 後にのべる)。この過程は実例の揃っている最南地方で は明確に知ることができ，また紀ノ川，吉野川流域の遺 構についても, これらの変遷とほぼ平行して同様の発展 を示していることが察知できたのである。なおナンド迴 りの方式は, ほぼ四間取りと平行するが，ナンドとザシ キ間は近代末になっても壁で閉されていて，この点に関 しても保守性をかなり強く残していることが分る。

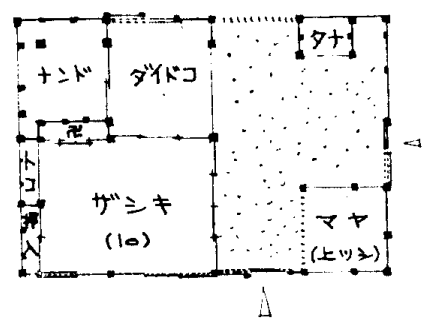

第 15 图蔽缘源郎家住宅復原平陌图

付, 㐘家源郎家住宅 (重文) 奈良県添上郡月瀬町大字 桃野（第 15 図参照）

42 年度文部省緊急調查 ${ }^{7}$ で発見され最近指定を受けた 家である。18 世紀前半の建築と推定されている。開取 りは表に 10 靚という広いザシキを持ち, 裹にナンドと ダイドコを配する三間取りであるが，ダイドコが士間方 へ突出していないので笽密には喰い違い三間取りとはい えない。しかし三室の配置や表裹を2 分する方式恰前記 のもの上極めて近似しているし，構造自体も異なるとこ ろがない。またこの種の遺構は，大阪府と合の周辺にも かなり現存することから，四間取りと窑接な関倸にある ことも推察できる(ただし大阪近辺の遣構は，いずれも はなはだ小規模で到底四間取りに造れないほどのもの で，かつ年代も 18 世紀に溯るものが見当らないので， これをもって四間取りの系統を㴊源的に落察することは 無理で西る)。ところで㐘家家住宅の場合は四間取りが 可能な規模を持ち, しかも 18 世紀前半にまで溯れる遺 構であることから，四間取り型の原型として喰い違い三 間取り型と共にその存在は注目す心゙きであろう（因みに 
箱水千年家などもあるいはこの種の型に復原できる可能 性も考えられよう)。しかし中世にまで湖って雨者の関 係を求めることは現在の資料では困難であるが，元来は 同じ系統の型と考えられる可能性もある。

\section{3. 四間取り民家の特色之異質性}

すでに述べたように，四間取り型民家が吉くから存在 する畿内の一部を除けば，他の地方では，広間型を主流 に，縦割型，一列立び型等の諸型が古くから存在してい たと考えられるのであるが(第 16 図)，このうち特に分 有の広い広閒型についてみると，四間取り型が普及する のは，㧍よそ 18 壮紀以後になって，漸く広間を分割し て, 四間取りへ移行し始めるが, 最も後進地域では 20 抴紀に入ってからであることが，近年の調查結果で次第 に明らかとなってきた。ところが畿内では 17 悩紀初頭 から四間取りが存在し，すでに遍く分布していたので, 間取りに関してもこの間実に 2 世紀前後のずれが流るこ とがわかる。

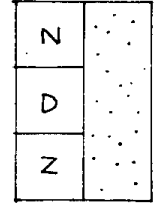

a. 淁入縰比型

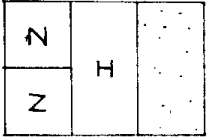

b. 底間型

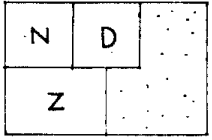

c. 喰い違い三間取り型
D. ダイドコ
N. ナン
Z.ザシキ

H. ヒロ マ

d. 一列证び型

第 16 図民家の面平図

ところで畿内の民家が早くから四閒取りをとっていた ことは䍩に畿内が先進地であったから，他所よりもそれ だけ早く広間型の三間取りから四間取りに移行したとい 5ものでなく，この雨形式の間には，もっと根本的な異 質性があり，むしろその四間取り民家の祖形を求めるな らば，泉南から紀，川，吉野川流域にわたって分布して いた喰い違い三間取り型の方が，構造的にも，機能的に もはるかに近新性があることについてはすでに指摘して おいた。しかしこのことは従来末だ明確に諭じられてい なかった点で，日本民家の系譜を考察寸る上からも重大 な提起となるものであるから，さらに広間型その他の采 統と比較することによって，その特質を明らかにして㧤 きたい。

(1) 平面の問題 ここでは泉南の喰い違い三間取り 型と，畿内に広く分布する四間取り型を同一系統の変種 とみて，喰い違い三間取りを広間型㧍よび妻入䋛割型の 間取りをとりあげて，比較してみることとしたい。現在 知られる限りでは，この三つの型が歷史も古く，少なく とも 1600 年前後まで実証的に溯ることができるもので ある。これら三つの基本的な間取りは，いずれもダイド

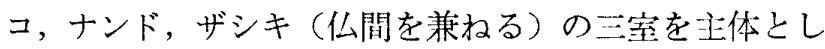
て成り立っている。このことは近世民家の成立を考える 上で重要な問題であるが，中揩の遗構が皆無に近いため に溯ってその成立を求めることは不可能である。しかし たい。

少なくとも 1600 年前後の時点では平醉計画上，この三 室が最少限必要な室であったと考えられる。そこで，こ の三室の動線計画に伴なう配置方法の組合せ方如何によ って幾つかの異種な空配列ができ上るわけであるが，奏 際には住生活の中心になるダイドコを核に配置を計画し ているので，組合せ方は自ら規制される。つまりダイド コは必ず土間に添い，かつナンドとザシキへ直接連なる ことが条件付けられ，ザシキも南面または，外からのア プローチのよい場所が択ばれる。そうすると作図すれば （第 16 図 a〜c）明らかなように，この三種類の組合せ はいずれもその条件に適合していることを知るのであ る ${ }^{8}$ 。ところでこの三型のうち, ナンド(4〜6 畳ほど) と ザシキ(6〜8胃ほど) 注どの型でもほぼ同じ広さを持っ ているのであるが，広閒型のダイドコのみは他の型より も特に長大な面積を占め, 異質な感をもつものである。 そこで次に三室の中心になるダイドコについて荐えてみ

\begin{tabular}{|c|c|c|}
\hline$\because$ & $N$ & $\ddots$ \\
\hline$Z$ & $D$ & $\ddots$ \\
\hline$D$ & & $\ddots$ \\
\hline
\end{tabular}

(2) 台所空閒の機能的問題 広間型の広間には，大きい炉を置いて炊 事兼食堂兼居間となっているが，喰い違い 三間取り型や綎割型では，ダイドコに大き い炉をおかず，土閒の裏当分にクドを設け て炊事全般を行なう場となり，ダイドコは 食堂（兼居間）の機能をもつのみであるた め,さほど広い室を必要としなかったと考えられる。つま り前者の広間に相当する空間は，後者のダイドコと土間 の裹半分を加えた空間となり，両者のダイドコに対する 考え方は根本的に異なるのである。その相暴は気候とも 関連するのか炉とクドの配置の相異に帰する点が多い。 なお畿内の四間取り民家では，クドの空間をカマヤとし て独立させるものが多数みられるが，こうなるとクドは 大きくなり,庭大告柱より煙り返し梁を入れて，その上に 小壁を設け，煙が居室方向に流れぬようにされている。

以上のように三つの型の基本的な室の配藽方式やダイ ドニの使い方が互に異質であることは，その成立の根元 においても翼なる素因をもっていたと推定できるが，次 にこれらの閏取りとも関逨のある構造について検討しよ 50

(3) 構造上の問題広間型と喰い違い三間取り型お よび四間取りの型との構造上の相異で一見して分ること は，前者は軸䂙と小屋構造が一体となって対称型に組ま れて，屋根裹まで架構を見せるのに対し，後者では軸部 と小屋構造は，梁上に水平な天井を張ることによって隔 離され，その小屋裏をツシとして用いていることであ る。つまり公間型では，比較的短い小羞梁 (二間前後) を身丟の両端（ときにはその中間）の身舎柱で支えるた め, この柱は居室の側柱（下屋柱）よりも高く延びて， 小屋裹にまで達しているが，喰い違い三閒取りや四間取 
り型では，長い小屋梁 (三間半前後)をほとんど居室の 梁行幅一ぱいに架けているのである。このような構造差 の発生理山は現在の资料から追求することは不可能であ

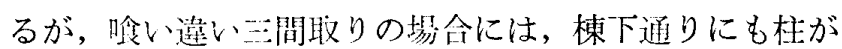
一間ごとにたち，水可の器以小幄梁をほぼ中央で支えて いるのであるが，これは元来㹨い梁閒の構造を裴裏に前 べて 2SPAN に令成された状態を示している。しかし 広閣型で注，小梁閭の建物を表裹に庇を抬大して発展さ せた状態を示し，発生的に推察しても雨者の異質性は強 、と考えられる。このような異なる発展をとってきたの は恐らく基本的な間职りが一方は室を表裹に交互に配し 飡い違わせていたのに対し，他方は表裹に長い広間を持 ち続けていたことによるものと考えられる。従って喰い 違い三問取りのこの構造方式は土間の作業空問を表側で 広くとることにさせるのであって，整型四間取りの場 合，土間を広くするのには桁行方向に太い梁を用いてそ の雨端の柱を特に太くすることとなった。

な扮西吉野の堀家住宅，兵庫紧の箱木，古井両千年家 などは（いずれも中世の遺構である）改造がはなはだし いので明膫でないが，主屋を表裹に分けて 2 SPAN と なる構造であり,この種の構造方式の古いことが知れ， 溯源的に広間型と異質な構造が極めて古くから乘立して レたことが想定できる。

(4) 四間取り移行に関する基本的問題 ところで, 元来必亚最小限度の要求であった三室に, 玄関的役割

（兼ザシキの次の間的性格）をもつクチノマが加わる段 階で, 前記三種の基本型はいずれも四間取りへと移行し 始めるのである。広間型の場合には単に玄関を表裹に分 割すれば四間取りになるが(もっとも実際には構造上そ

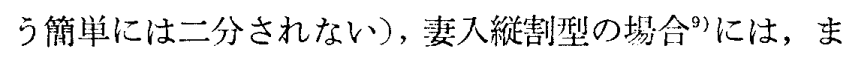
ずダイドコとナンドが並列されて，あたかも喰い違い三 間取りの型のようになるが（ただしダイドコの突出する ものは少ない, また構造的には雨者は買質である), 次 にザシキが広くなり，梁行抾も拡大寸る中で，ザシキ が二分されて四間取りへと移行する。

ところで喰い違い三間取り型の場合は，すでに述べた ように，やはりザシキを分割して細長いクチノマを作 り次にダイドコとの喰い違いを修正して四間取りへ移行 するが，このように喰い違いを修正した場合は，構造的 に上間幅を広くしょうとすると, その梁架構が困難にぶ つかる。この解決方法はすでに記した通りである。なお 整形四間取りでは室境に広い開口を要求されるので, 差 鴨居を使用することとなる。畿内の四間取りではこの差 鴨居がすでに 17 紀初頭に使われており（五条市，栗 山家住宅, 慶長 12 年-1607一の町家 ${ }^{10)}$ ), その発生が 他の地方に比べてはなはだ早く，しかも土間と居室境に もこれを用いることは，広間型では 18 世紀中頃以降で ないと実例を見ないことから考えて，その発生は極めて
早いことが特色づけられる。このように四間取り移行の 経過からみても畿内の四閣取りは喰い違い三間取り型か ら土間の梁構架を克服与ることにより, 発展できる要因 をもち, しかも両者の間には, 室の配列の基本的な類似 はもとより, 構造方式は全く同種であって, 広間型等の 系統とは湖源的に埧翼であると考えざるを得ないのであ る。

以上考察したように, 畿内の四間取り型の間取りや構 造上の特徵は，全国に広、分布をもつ広閒型とは全然異 質であり，この型から発展したとは考えられず，むしろ 泉献から吉野川筋を中心に存在寸る喰い違い三間取り之 はなはだ共通していて，その発展したものと考えるのが 自然に思われる。ところで四間取りを含むその古い分布 範团は, 北は縦割型で境され, 㑲は十津川谷の一列並び 型 ${ }^{11)}$ で境されていて，広間型とは，わずかに東は伊賀盆 地と滋賀県束部を限って接しているにすぎず，西はゆ国 地方に広間型を認めるので，この分布範囲は畿内の一部 に限定されるようであり，しかもこの四閒取り民家と喰 、違、民家とは同じ府下の旧宗北, 泉南曱郡で隣接して いるので, 分布の上からみても, 喰い違い三間取り型と 四間取り型とは極めて近い関係にあると考えられるので ある。

\section{結 語}

本稿では大阪府を中心として分布する四間取り民家の 高密度の資料蒐集と復原結果に基づいて，その平面と構 造の特色および 17 世紀以降の变遷を追求し，かつ新た に発見された喰い違い三間取り型民家の調查結果をまと め, その古形式と, 四間取りへの変遷経過を明らかにし た。その結果に基づいて，全国に主流をなすとみられる 広間型と，またそれとは別系統と考えられる妻入縦割型 の雨者と比較し, 平面, 機能, および構造上の諸点にお いて, 畿内の四間取り型は溯源的に考えて広間型や縦割 型とは別系統のものであり，むしろ隣接地に分布する喰 い違い三閒取り型を祖形とする考え方が妥当であるとの 結論に達した。こうして, はじめて従来吥究の盲点であ った畿内の四間取り型の成立事情を推定し，その特質を 明らかにすることができた。

\section{註記}

1）大河直躬「四間取りの成立」 1959.5 建築雉新，および太 任愽太郎著「書院造」p. 33, 1966.10 東大将版会など参 照

2）浅野济，林野全孝共著「大阪府の民家II」1967.3 大阪

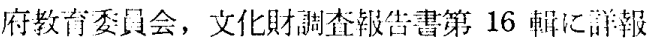

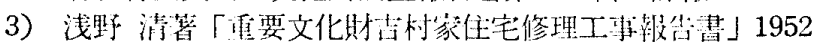
大阪府教管委員会

4）林野全孝, 占田高子「村扏好之助家の普請について」 1967.10 建築学会諭文報告集号外 p. 1004

5）林野全孝，吉田高子「奈氺紧生駒郡の大工松斗理一家文 書」 1968.10 建築学会論文報告集号外 p. 853

6）浅野消，林野全孝共蓄「大阪府の民家 且」大阪府教育

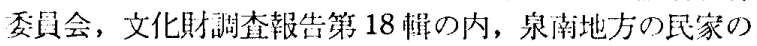
项参照 
7）奈是国立文化財研究所の调查に基ずくもので，闰所の御 教示によった。

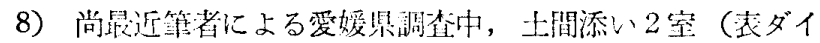
ドコ，垶ナンド）と舆に 1 等（ザシキ）を有する三聞取 り型の古形式を発ししたが，ての見解については後日発 永した。

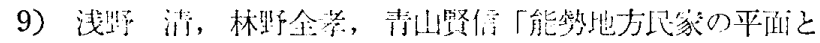

構造の古形式」「同, 民家平面の変動過程」1961.10 学会 論文報告勧 63, p. 813, 817. および浅野 清, 青山賢信 共著「能勢の民家」1965 日本民家集落博物館䁷報 II

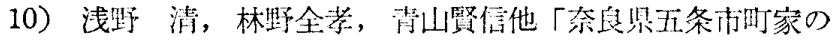
編年々建築的济速」「同, 平直の型」 1959.10 建築学会諭 文報售 63 , p. 601, 665

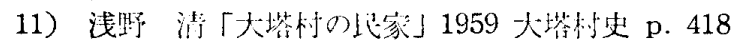




\title{
AN ANALYTICAL SURVEY OF THE FOUR-ROOMED FARM HOUSES CENTRED AROUND OSAKA PREFECTURE/ITS TRANDITION AND CHARACTERISTICS
}

\author{
by Dr. MASANORI HAYASHINO* \\ Member of A.I.J.
}

The purpose of this study is to clarify the characteristics and the changes of the farm houses in the Edo ear in and around Osaka prefecture. In order to pursue this study, I have collected a lot of materials of the farm houses in Osaka prefecture and its vicinities. On the collected materials, I have made a historical survey by restoring them in to their original status. I have seen a great number of the farm houses in question all over the country and I do esteem their existence and value.

Chapter I deals with the restoration of the four-roomed farm houses in the Kinki District, but mainly in Osakia Prefecture and I have primarily studied the transition of the plan in connection with its construction. As a result, I have as certained that the space of the bedroom ("Nando") graduelly had been changed from a closed roomed type into a spacy, airy one, by eliminating some of the surrounding pillars, connected every " 1 ken" (about two meters) which formed the room. Also the wall accessories gradually had been removed. In other respects, there hardly had been made any changes throughout the three hundred years since 17 th century.

In Chapter II, by investigating and restoring the farm houses in the Sennan District, in the basin of the river Kino and in the Nishi-Yoshino District, it has become clear that in the three-roomed farm houses the Dinig Room projects into on unfloored space in the house. By considering these results of restoration and pursueing the original type as well as searching for the progress of transition and changes up to the completion of the four-roomed type, it has been proved that the characteristics of the construction method and the plan are very similar to those of the fourroomed type in the previous chapter.

By studying the historical progress of the farm housess, Chapter III gives a whole view on how other studies have been made so far concerning the farm houses' origin. At first, it was influentially thought that the farm houses were of a four-roomed type, but it has been definitely found by restoring them that the four-roomed type in the greater part of the country originates from the three-roomed type ("Hiroma" type). As a result, I came to the conclusion that the "Hiroma" type was once rather prevalent.

But it has been proved that the four-roomed type in Osaka Prefecture cannot be restored into the three-roomed type of house and rather has a close relation concerning its construction and function with the three-roomed type, the Dining Room of which projects into the unfloored space, so called "Kuichi-gai-mima-dori" : the three-roomed interlocking type. The fourroomed type of farm houses in the Osaka Prefecture is quite different in itself from of the other districts.

The construction of the three-roomed type ("Hiroma type") consists of a principal part called "Moya" and an additional part callec "Hisashi". On the other hand the three-roomed interlocking type, "Kuichi-gai-mima-dori", and the four-roomed type are characterized with continuous beams on wich the roof frame is built, according to the plan consisting of a front and rear division. In the ; "Hiroma" type, the Dining Kitchen is called "Hiroma". In the "Kuitchigai-mima-dori" type the kit- | chen is unfloored and one of the three rooms is used as the Dining Room. Thus, for the reasons

\footnotetext{
* Assistant Prof. of Kinki Univ.
} 
mentioned above, the two types proved to be quite different.

In the environs of the plains of Osaka and in the Nara basin, the four-roomed type of farm houses is popular, whereas in the North of Osaka Prefecture the "Tsumairi-tatewari" type was built. The plan of the "Tsumairi-tatewari" type is divided into two parts, one for an unfloored space and another for the rooms which run parallel with the ridge. Those of the "Hirairi-ichiretsu" type, the plan of which consists of several rooms adjoint are situated in the South mountainuous districts.

Because of the above reasons, it is quite possible and gives good reason that the four-roomed type of the Central District is hardly connected with the "Hiroma" type of the districts around Osaka. In addition to that, the four-roomed type in the "Kinki" District is quite different from the others in all other districts, and I came to the conclusion that it has rather something in common with the threeroomed interlocking type and it could be possible that the three-roomed type was of the original type.

Though many known studies on the four-roomed type of farm houses in the "Kinki, District have not clarified its origin, type and characteristics I succeeded in defining them. 


\title{
STUDIES ON THE METHOD TO MEASURE AND JUDGE THE DENSITY OF BUILDINGS (Part II)
}

-Actual Measuremnts of Sky-Factors at Tokyo, Nagoya and Osaka and Considerations on Density-

By Dr. MASAAKI TAKEI, Associate Professor of Tokyo University of Science, Member of A.I.J.

By the method shown in Part I, we actually measured sky-factors at main districts in Tokyo, Nagoya and Osaka and investigated the densities at the districts and considered inferior limits of desirable densities there, classifying skyfactors densities in grades.

We calculated the densities of several cities at the time when the buildings will be constructed to the utmost limit under the Building Act. This calculation shows that both Nagoya and Osaka will have much worse conditions in density of building than today and also after being appointed as "bulk-district" probably their densities will be higer than Tokyo. Therefore, when the bulk regulation is to be enforced, the regulations on coverage and set-back of building line should be carefully considered at the same time.

U.D.C. $69.008: 331.8$

\section{A STUDY ON WORKER OF CONSTRUCTION INDUSTRY (No. 2)}

(Distribution of worker and specific character of workers' market)

By Master of arts. YUKIY ASU NAKAMURA, Tutor Meiji Univ. Member of A.I.J.

Chapter 3. \& Chapter 4.

Postcoript

Bibliography

U.D.C. $728.6 .03(521.7)$

\section{AN ANALYTICAL SURVEY OF THE FOUR-ROOMED FARM HOUSES CENTRED AROUND OSAKA PREFECTURE}

-Its Trandition and Characteristies (See Page 83)

By Dr. MASANORI HAYASHINO, Assistant Prof. of Kinkkı Univ. Member of A.I.J.

U.D.C. $72.03: 725.172$

\section{THE STUDY OF THE RECEPTION ROOMS IN THE PROVISIONAL IMPERIAL PALACE DESIGNED BY C. DE BOINVILLE (Part 1)}

\author{
By SHIGEKATSU ONOGI, Chief Engineer. Building and Repair- \\ ing Section, Imperial Household Agency, Member of A.I.J.
}

A building used as the reception rooms in the provisional Imperial Palace, Akasaka, Tokyo, was designed by C. de Boinville, an architect of the KOBUSHO (The Department of Public Works).

It was the first European style's buildings built for the Japanese Court and the construction was started in September 1876. But the construction was discontinued because of a damage by an earthquake in March 1879 .

This study intends to give the entire picture of this building on the basis of a lot of records.

In the present paper details of the progress after the first planning are described. 